\title{
PEMIKIRAN HARUN NASUTION TENTANG PENDIDIKAN MORAL
}

\author{
Syafi'ah \\ UIN Sultan Syarif Kasim Riau \\ syafiahsaid12@gmail.com \\ Muh. Said HM \\ UIN Sultan Syarif Kasim Riau \\ saidsyafiah@gmail.com
}

\begin{abstract}
Abstrak
Harun Nasution (1919-1998) termasuk salah seorang tokoh intelektual muslim pembaharu dalam bidang pemikiran Islam rasional dan berpengaruh besar dalam memahami dan menjelaskan ajaran-ajaran agama dengan tetap diilhami substansi pesan moral wahyu Allah. Menurutnya dengan kemampuan daya nalar rasio manusia akan menemukan pengetahuan dan kebenaran, nilai-nilai dan pesan-pesan moral. Sementara dalam hal proses pendidikan moral itu sendiri harus rasional, yakni dalam prosesnya dapat diterima oleh rasio disamping harus juga selaras pula dengan tingkat perkembangan rasio anak didik. Keselarasan proses pendidikan moral dengan nalar rasio, akan dapat melahirkan anak didik yang tidak hanya memiliki kecerdasan intelektual semata, tetapi sekaligus memiliki moral mulia. pengetahuan yang dimilikinya akan senantiasa sejajar dan sejalan dengan prilaku sosialnya, sehingga ada harapan menjadi manusia pencerah sosial shaleh.
\end{abstract}

Kata Kunci: Pemikiran Harun Nasution, Pendidikan Moral.

\begin{abstract}
Harun Nasution (1919-1998) was one of the reformer Muslim intellectual figures in the field of rational Islamic thought and had a major influence in understanding and explaining religious teachings while still being inspired by the substance of the moral message of God's revelation. According to him, with the ability to reason, human reason will find knowledge and truth, values and moral messages. Meanwhile, in the case of the moral education process itself, it must be rational, that is, in the process it can be accepted by the ratio, besides it must also be in accordance with the level of development of the ratio of students. The harmony of the moral education process with rational reasoning will be able to give birth to students who are not only intellectual, but also have noble morals. the knowledge they have will always be parallel and in line with their social behavior, so that there is hope of becoming a pious social enlightened human.
\end{abstract}

Keywords: Harun Nasution's Thought, Moral Education. 


\section{Pendahuluan}

Sumbangsih atau kontribusi pemikiran-pemikiran Islam rasional di dunia Islam, dalam memahami, menjelaskan dan mengajarkan ajaran-ajaran agama, ternyata dalam perkembangannya menurut (Nasution, 1979, h. 56) muncul sejak pada zaman klasik, yang oleh para sejarahwan diperkirakan sejak tahun 650-1250 M. Hingga seterusnya perkembangannya dalam studi Islam, ternyata pengaruh pemikiran Islam rasional tersebut terutama di Nusantara Indonesia hingga dewasa ini cukup pesat, mengalami kemajuan dan perkembangan dalam berbagai aspek kajian-kajian ilmiah terutama dalam bidang areal filsafat dan sains. Kaum pemikir rasionalis ini, merupakan suatu aliran yang semulanya menganut paham atau pemikiran teologi yang lebih banyak mengandalkan kepada kekuatan dan dominasi daya nalar rasio (akal), karena dengan dominasi daya nalar akal manusia menurutnya mempunyai daya analisis yang kuat dan akurat serta akan mampu memberikan nalar ijtihadi atau interpretasi secara liberal terhadap ajaran-ajaran agama, terutama terhadap ayat-ayat al-Qur'an dan al-Hadits Nabi SAW (Abdul Nata, 1995, h. 61). Golongan yang membawa persoalan-persoalan teologi yang lebih mendalam dan bersifat filosofis dari pada persoalan-persoalan yang dibawa kaum khawarij dan Murji'ah, dan dalam berbagai pembahasan mereka lebih banyak mengandalkan dominasi nalar akal, sehingga mereka itulah yang mendapat nama populer sebagai kaum rasionalis Islam (Nasution, 1986, h. 38).

Menurut pemikiran kaum rasional agamis, bahwa pada hakikatnya manusia mempunyai kebebasan dan akal mempunyai fungsi dan kedudukan yang tinggi dalam memahami substansi ajaran-ajaran agama melalui kedua sumber referensi utama, yakni al-Qur'an dan al-Hadits. Kebebasan daya akal manusia hanya terikat pada ajaran-ajaran yang absolut kedua sumber utama syariat Islam itu. Maksud ayat-ayat al-Qur'an dan alHadits dipahami dan ditangkap pesan moralnya sesuai dengan daya kemampuan pendapat akal manusia. Dengan demikian, timbullah interpretasi dan pemahaman yang bercorak majazi atau metaforis dari teks (lafadz) ajaran-ajaran dasar yang terdapat dalam dua sumber primer tersebut. Memberikan isyarat, bahwa dalam pemikiran rasional agamis oleh kaum rasionalis, mereka mengusahakan pemahaman-pemahaman terhadap ayat-ayat al-Quran dan al-Hadits sedemikian rupa (maksimal) sehingga sesuai dengan kemampuan daya nalar dan pendapat akal dengan syarat sepanjang tidak bertentangan dengan substansi ajaran atau pesan-pesan moral wahyu itu sendiri 
(Nasution, 1996, h. 9). Manusia diciptakan oleh Allah SWT memiliki daya-daya tertentu yaitu daya berfikir (nalar), daya berkemauan dan daya bernafsu. Daya berfikir merupakan kekuatan tertinggi pada diri manusia, di mana ketinggian, keutamaan dan kelebihan manusia dari makhluk lain terletak pada akalnya. Kekuatan akal berpotensi menolong jiwa pembeda untuk mempertahankan keadilan dan mendahulukan fahamfaham yang benar, serta menjadikannya keyakinan atau imani dengan mengikrarkannya dengan lisan dan melahirkannya dalam perbuatan. Dengan akal, jiwa manusia merasa didorong untuk berbuat ketaatan dan membenci penyimpangan-penyimpangan dari yang benar, serta menolak ajakan kejahatan dan syahwat (Hazm, 1978, h. 8). Dengan akal-lah yang membuat manusia mempunyai kebudayaan dan peradaban yang tinggi, karena dengan kekuatan akal (rasio) yang dimilikinya, manusia mampu mewujudkan ilmu pengetahuan dan teknologi, selanjutnya ilmu pengetahuan dan teknologi yang membuat manusia dapat mengubah dan mengatur alam sekitarnya demi untuk kesejahteraan dan kebahagiannya, baik pada masa kini maupun pada masa-masa mendatang. Menurut pemikir kaum rasionalis, akal (rasio) dapat mengetahui perbuatan baik dan buruk, dan karenanya akal pada akhirnya dapat mengetahui bahwa berbuat buruk adalah buruk, dan berbuat baik adalah baik, dan pengetahuan inilah yang memastikan adanya perintah dan larangan. Selanjutnya, akal dapat juga mengetahui bahwa bersikap adil dan lurus adalah baik, dan bersikap tidak adil dan tidak lurus adalah buruk. Akal memerintahkan manusia mengerjakan perbuatan-perbuatan yang akan mempertinggi status derajat kemuliaan dan melarang manusia mengerjakan perbuatan-perbuatan yang membawa pada kerendahan derajat (Nasution, 1986, h. 89).

Para pemikir Islam rasional yang mengutamakan proses daya kemampuan akal, melihat bahwa wilayah keputusan moral amat luas dan berkesimpulan bahwa manusia yang sehat dapat mengetahui dengan akalnya akan perbuatan baik dan buruk. Tindak laku perbuatan baik disebut suatu kewajiban atau keharusan, seseorang akan memperoleh celaan apabila tidak mengerjakannya, kemudian tindak laku perbuatan disebut buruk atau jahat jika pelakunya akan memperoleh celaan apabila mengerjakannya, dengan demikian, akal (rasio) mampu mengetahui dan memperoleh kebenaran, namun harus tetap dalam bimbingan wahyu, sedangkan kebenaran dan kebajikan merupakan inti dari ajaran moral itu sendiri. Moral sebagai sarana dan wilayah ukuran baik dan buruk dari perbuatan manusia dapat dicari dan diketahui 
melalui daya kemampuan dan kekuatan daya rasio (akal) manusia. Moral seseorang tidak dapat tumbuh dan berkembang dengan sendirinya, tetapi harus selalu ditumbuh kembangkan dalam diri seseorang melalui proses bimbingan dan pendidikan. Pendidikan adalah usaha sadar dan terencana untuk mewujudkan suasana balajar dan proses pembelajaran agar peserta didik secara aktif mengembangkan potensi dirinya untuk memiliki kekuatan spiritual keagamaan, pengendalian diri, kepribadian, keserdasan, akhlak mulia, serta keterampilan yang diperlukan dirinya, masyarakat, bangsa dan negara (Depdiknas, 2006, h. 5). Oleh karena itu, pembentukan moral seseorang melalui tahapan-tahapan proses pendidikan yang baik (Islami), akan sangat boleh jadi ilmu pengetahuan yang dimiliki dan dikuasainya di backing oleh moral atau akhlaknya, karena antara agama dan ilmu pengetahuan keduanya saling terintegrasi (Putra, 2020). Artinya, akan mampu menempatkan penegakan moral di atas ilmu pengetahuan, dan hal tersebut merupakan suatu keharusan bagi setiap orang, karena idealnya memang bahwa moralitas harus berada di atas ilmu, karena ternyata keberilmuwan itu sendiri tidak selalu menjamin penegakan moral. Betapa banyak orang yang berilmu melakukan pelanggaran-pelanggaran sosial dan moral, bahkan sudah merupakan suatu kebanggaan sosial, betapa banyak orang yang berilmu, (ilmuwan agama Islam sekalipun), tidak berprilaku sejajar dengan ilmu yang dimilikinya (Harahap, 2005, h. 103). Untuk memahami lebih lanjut dalam tulisan berikut, bagi penulis merasa penting artinya sekaligus menjadikan alasan karena Harun Nasution sebagai salah seorang intelektual muslim, tokoh pembaharu pemikiran islam rasional nusantara, pada akhirnya dapat diketahui bahwa ternyata pemikiran islam rasional Harun nasution dalam hal pendidikan moral pada khususnya ada sisi relevansinya.

\section{Mengenal Harun Nasution}

Harun Nasution, lahir pada hari Selasa 23 September 1919 di Pematang Siantar, sebuah kota kecil di bagian Selatan Sumatra Utara. Ia lahir sebagai anak ke empat dari lima orang bersaudara, dari pasangan suami isteri bernama Abdul Jabbar Ahmad dengan Maimunah. Abdul Jabbar Ahmad, salah seorang ulama yang menguasai kitab-kitab jawi dan suka membaca kitab kuning berbahasa melayu. Pernah menjabat sebagai Kepala Agama merangkap Hakim Agama dan Imam Masjid di Kabupaten Simalungun. Sementara Ibu Maimunah, seorang boru mandailing, juga keturunan seorang ulama 
yang pernah bermukim di tanah suci Makkah dan mengikuti beberapa kegiatan di Masjidil Haram. Harun, berasal dari keturunan yang taat beragama, termasuk keturunan yang terpandang dan mempunyai latar belakang ekonomi yang cukup mapan. Kondisi keluarga seperti inilah menurut Ariendonika, menyebabkan Harun bisa lancar dan suskes dalam melanjutkan cita-citanya mendalami ilmu pengetahuan, yang pada gilirannya menjadi sosok pemikir dan intelektual muslim ternama di kemudian hari (Suminto, 1989, h. 1-5). Harun memulai pendidikannya di Sekolah Belanda, Hollandeh Inlandeche School (HIS) pada waktu usia 7 tahun. Di samping belajar bahasa Belanda dan ilmu pengetahuan umum di HIS itu, juga memulai belajar agama dari lingkungan keluarganya dengan mengaji, shalat dan ibadah lainnya. Setelah tamat di HIS, melanjutkan ke Sekolah agama yang bersemangat modern yaitu Moderne Islamictische Kweekschool (MIK), atau Sekolah Guru Menengah Pertama Swasta Modern, semacam MULO di Bukttinggi. Berkat didikan di MIK, sekap keberagaman mulai berubah, menyebabkan orang tuanya dipindahkan belajar agama ke Arab Saudi (Mekah), seterusnya setelah itu harus meneruskan pendidikan ke Mesir. Akhirnya pada tahun 1938, Harun melanjutkan studinya ke Universitas Al-Azhar Cairo Mesir, lebih mendalami Islam pada Fakultas Ushuluddin, namun tidak merasa puas, sehingga pindah ke Universitas America di Cairo, dengan mendalami Ilmu Pendidikan dan Ilmu Sosial, dan akhirnya tamat pada tahun 1942 dengan memperoleh ijazah Sarjana Muda (BA).

Setelah hampir 20 tahun bekerja sebagai Pegawai Departemen Dalam Negeri dan kemudian menjabat sebagai sekretaris pada Kedutaan Besar Indonesia di Brussel, maka dengan berkat penawaran untuk kuliah di Canada, akhirnya pada tanggal 20 September 1962, Harun berangkat ke McGill-Canada, dengan lebih mendalami lagi Islam di Institute of Islamic Studies McGill Montreal Canada. Selama 2 tahun di McGill, Harun dapat menyelesaikan kuliahnya dan memperoleh gelar akademik Master of Art (MA) dengan judul tesis The Islamic State in Indonesia: The Rice of Ideology, the Movement for its Creation and the Theory of the Masjumi. Selanjutnya, Harun-pun meneruskan studinya, dan dalam waktu dua setengah tahun berikutnya, tepatnya hingga pada bulan Mei 1968, ia pun menyelesaikan studi program doktor dengan memperoleh gelar Doktor (Ph.D), dengan judul disertasi Posisi Akal dalam Pemikiran Teologi Muhammad Abduh. Setelah itu, sejak 27 Januari 1969, Harun kembali ke tanah air Indonesia, dan secara resmi berada di Jakarta dengan mengabdikan diri sebagai dosen, baik di UI Jakarta terlebih-lebih di civitas akademika IAIN Syarif Hidayatullah Jakarta, 
sebagai awal dalam upaya mengembangkan pemikiran-pemikiran keislaman (Halim, 2001, h. 14-15).

Harun Nasution, sejak perjuangan pengabdiannya di dunia akademik dalam upaya pengembangan keilmuannya, selama itu pula telah melahirkan berbagai hasilhasil karya ilmiah, baik dalam bentuk tulisan artikel atau makalah, maupun dalam bentuk buku-buku cetak. Antara lain misalnya judul-judul karya ilmiah dalam bentuk buku cetak, adalah: Islam Ditinjau dari Berbagai Aspeknya (1974), Teologi Islam: Aliran-aliran Sejarah, Analisis dan Perbandingan (1970, Filsafat Agama (1978), Filsafat dan Mistisisme dalam Islam (1978), Pembaharuan dalam Islam: Sejarah Pemikiran dan Gerakan (1978), Akal dan Wahyu dalam Islam (1980), Muhammad Abduh dan Teologi Rasional Mu’tazilah (1987), dan Islam Rasional Gagasan dan Pemikiran (1995).

Sementara posisi penting yang pernah dijabat sebagai amanah padanya, antara lain: Wakil Rektor I IAIN Syarif Hidayatullah Jakarta, dan akhirnya pada tanggal 4 Juni 1973 oleh Menteri Agama Prof. Dr. Mukti Ali, melantik Harun Nasution sebagai Rektor IAIN Syarif Hidayatullah Jakarta menggantikan Prof. Thaha Yahya, yang sudah tidak bisa aktif lagi karena jatuh sakit. Harun, sebagai Rektor IAIN Jakarta selama 11 tahun (1973-1984), disamping itu juga pada tahun 1982 menjabat sebagai Ketua Lembaga Pendidikan Agama IKIP Jakarta, dan menjadi Dekan Fakultas Pascasarjana IAIN Syarif Hidayatullah Jakarta. Menurut komentar salah seorang tokoh Husni Rahim dikatakan, bahwa Harun Nasution bagi saya adalah sebuah inspirasi dan semangat bagi perkembangan kajian studi-studi Islam di Nusantara Indonesia. Harun adalah tokoh yang menghabiskan segenap umurnya bagi peningkatan kualitas lembaga pendidikan tinggi agama Islam di Indonesia. Atas dasar tersebut, sangatlah beralasan jika diusulkan menjadi tokoh pendidikan di bidang Islamic Studies. Tokoh penggagas Islam rasional ini sangat layak mendapatkan itu, karena karya dan hasil kerjanya sangat nyata, yaitu semacam tradisi intelektual di mana orang berani berdebat secara terbuka, berani mempertanyakan sesuatu yang selama ini dianggap sudah mapan. Tradisi kehidupan intelektual seperti itu terus berlanjut hingga ia wafat pada hari Jum'at bertepatan 18 September 1998 di Jakarta dalam usianya 79 tahun kurang 5 hari (Suminto, 1989, h. 40$41)$. 


\section{Gagasan Pemikiran Islam Rasional}

Tidak dapat dipungkiri, terutama oleh kalangan generasi muslim Nusantara Indonesia, kontribusi dan peran aktif keilmuwan serta berkah perjuangan Harun Nasution sejak dari tahun 1973-1998, sebagai sosok tokoh intelektual muslim yang senantiasa menggagaskan dan menawarkan pemikiran-pemikiran ilmiah dalam berbagai kesempatan sebagai upaya dalam mengembangkan pemikiran-pemikiran Islam rasional. Menurut Harun, bahwa sesunggunya dan pada umumnya di kalangan masyarakat bangsa Indonesia terdapat kesan yang mendalam dalam pemahaman mereka bahwa Islam bersifat sempit, atau dengan kata lain ajaran-ajaran Islam mereka pahami secara sempit, hal tersebut dikarenakan salah pemahaman dan pengertian mereka tentang hakikat Islam itu sendiri. Masyarakat pada umumnya hanya mengenal Islam dari aspek ibadah, fikih dan tauhid saja, dan itu-pun hanya menurut satu mazhab dan aliran tertentu saja. Pada hal, menurut Harun lebih lanjut bahwa substansi dan keluasan cakupan ajaran-ajaran Islam itu, baru dapat ditampilkan bilamana Islam tidak hanya dipahami sebatas aspek ibadah, fikih dan tauhid saja, tetapi juga mempunyai aspek filsafat, teologi, mistisisme dan pembaharuan dalam Islam (Yusuf, 1989, h. 125-126). Menurut Suminto (1989, h. 3) bahwa ada dua obsesi Harun yang paling menonjol, yakni membawa umat Islam kearah berpikir dan menjalani kehidupan keagamaan dalam segala aspeknya, dalam kerangka berpikir rasionalitas dan bagaimana agar di kalangan umat Islam di Indonesia ini tumbuh pengakuan atas kapasitas manusia Qadariyah, yakni manusia yang mempunyai kemerdekaan dan kebebasan dalam menentukan perjalanan hidupnya, mempunyai kebebasan dan kekuatan sendiri untuk mewujudkan perbuatanperbuatannya. Timbulnya kesalah pahaman bahwa ajaran-ajaran Islam sempit dan tidak sesuai dengan kemajuan modern, disebabkan karena hanya mengetahui satu mazhab (aliran) saja, ada hal-hal yang dianggap haram, sedangkan sebenarnya hal itu haram menurut mazhab tersebut dan tidak menurut mazhab lainnya. Demikian pula kesalahan pahaman bahwa Islam mengajarkan fatalisme, sedangkan ini sebenarnya adalah ajaran dari satu aliran tertentu dalam Islam. Dengan adanya pandangan dan pemahaman mereka yang tidak secara menyeluruh (kaffah) terhadap ajaran-ajaran Islam itu sendiri, maka pada gilirannya menimbulkan kejumudan di kalangan masyarakat, terutama di kalangan umat Islam itu sendiri. Oleh karena itu, bilamana umat Islam terutama di Indonesia tidak ingin mengalami ketertinggalan dalam berbagai aspek kehidupan, maka 
harus berani meninggalkan pemahaman-pemahaman yang sempit terhadap Islam dan merubah sikap mental yang selama ini menjurus ke fatalistik.

Dari berbagai gagasan rasional yang dikemukakan dan dikembangkan oleh Harun, tampak bahwa Islam sesungguhnya bukanlah agama yang sempit dan hanya dalam satu aspek saja, tetapi mencakup berbagai aspek sebagaimana ia tulis dalam salah satu buku perdananya hingga dua jilid berjudul Islam Ditinjau dari Berbagai Aspeknya seperti aspek; teologi, fikih, filasafat, moral, hukum, sejarah, mistisisme dan sebagainya. Kejumudan masyarakat umat Islam Nusantara selama ini dikarenakan masih kental dan kuatnya pemikiran-pemikiran tradisional yang menyebabkan pandangan dan pemahaman yang sempit dan fanatisme di kalangan masyarakat. Dalam masalah teologi misalnya, alam pemikiran tradisional banyak berpegang pada kehendak mutlak Tuhan, sehingga semua yang ada di alam ini menurut mereka berjalan sesuai dengan kehendak mutlak Tuhan dan manusia hanya menunggu berlakunya kehendak mutlak Tuhan. Dalam teologi tradisional, tidak terdapat konsep kausalitas, karena itu sains dan pemikiran filosofis tidak berkembang, di dalam menghadapi tantangan dan kemajuan zaman kurang kreatif dan inovatif. Sedangkan dalam teologi rasional, yang dihasilkan pemikiran filosofis dan ilmiah terdapat konsep bahwa Tuhan mengatur alam ini sesuai dengan sunnatullah, yaitu hukum alam ciptaan Tuhan, dengan demikian penganut teologi rasional bersikap dinamis dan percaya pada kausalitas (Nasution, 1996, h. 177-178). Oleh karena itu, untuk meraih kemajuan dalam berbagai aspek kehidupan, maka umat Islam harus berpegang pada pemikiran yang rasional. Dengan pemikiran rasional umat Islam akan memiliki pengetahuan yang komprehensip tentang ajaran-ajaran Islam dan tidak berpandangan picik terhadap perubahan dan kemajuan zaman. Islam dengan ajaran-ajarannya merupakan agama universal yang sesuai untuk segala tempat dan zaman, untuk itu Islam sangat dinamis, fleksibel dan dapat menerima perubahan dan kemajuan zaman atau modernisasi. Dengan kata lain, sifat universal yang disertai dengan ciri khas fleksibelitas, menunjukkan prinsip-prinsip bersifat terbuka, cara-cara pelaksanaannya dapat ditentukan mengikuti kebijaksanaan yang sesuai dengan konteks sosial tertentu serta konteks kekinian dan kedisinian (Umar, 2007, h. 48).

Al-Qur'an al-Karim, menurut Abd al-Wahhab Khallaf sebagai kitab wahyu agama Islam memang mengandung berbagai ajaran, baik yang bersifat ibadah maupun 
mu'amalah, tetapi tidak secara jelas tidak tergambar bagaimana pelaksanaan ibadah dan mu'amalah yang harus dikerjakan oleh umat pengikutnya. Bahkan, ayat-ayat ahkam mengenai hidup kemasyarakatan itu, selain kecil jumlah keseluruhannya, bersifat umum, dalam arti hanya memberi garis-garis besar saja tanpa perincian lebih lanjut. Untuk itu, diperlukan interpretasi (penafsiran ilmiah) melalui pemahaman rasio (dominasi akal) sesuai dengan kondisi yang ada (Khallaf, 1956, h. 34-35). Dengan demikian, memberikan isyarat bahwa Islam membuka lebar-lebar pintu ijtihadi (analisis rasional), sedangkan proses ijtihadi itu sendiri tentunya secara otomatis mempergunakan pemikiran-pemikiran yang rasional pula (Tebba, 1989, h. 136-137).

Islam rasional sebagaimana telah diungkapkan, merupakan salah satu corak paham keislaman yang di dasarkan pada kemampuan daya akal (rasio) manusia. Islam rasional dapat diartikan sebagai Islam yang dalam menjelaskan ajaran-ajarannya tidak hanya mengandalkan pendapat wahyu, tetapi juga mengikut sertakan akal-pikiran manusia, sehingga meskipun mempergunakan kekuatan daya rasio namun tetap dalam bingkai bimbingan wahyu (Abuddin Nata, 2000, h. 62). Islam merupakan agama yang rasional, karena itu sangat menghargai kekuatan daya rasio yang dianugrahkan Tuhan kepada manusia. Sebagai agama yang rasional, Islam memberikan alternatif kebebasan kepada manusia untuk mengatur masalah-masalah yang berkaitan dengan kemashlahatan hidup di dunia. Dengan demikian, Islam rasional yang dimaksud dalam konteks gagasan dan penawaran pemikiran sosok intelektual muslim Harun Nasution ini, adalah bahwa ajaran-ajaran Islam itu dapat dipahami dan diterima oleh kekuatan daya akal (rasio), sedangkan rasio sendiri dapat dipergunakan untuk memecahkan segala persoalan-persoalan yang dihadapi oleh umat Islam (masyarakat) dengan tetap berpedoman teguh kepada al-Qur'an dan al-Hadits sebagai sumber utama dalam ajaran Islam, disamping sumber hukum yang disepakati eksistensinya, antara lain misalnya; alIjma dan al-Qiyas, dan juga sumber hukum yang belum disepakati eksistensinya, misalnya; al-Istidlal, al-Syar'u man Qablanan, al-Istihsan, al-Mashalih al-Mursalah, al'Urf dan sebagainya (Al-Qardhawi, 1987, h. 46)

\section{Substansi Pendidikan Moral}

Sesungguhnya masalah pendidikan moral ini dalam sejarah dan kajian akademis sudah lama dipermasalahkan dan selalu diperbincangkan seiring dengan perkembangan 
pemikiran-pemikiran filsafat dimulai dari pernyataan Meno yang terkenal itu kepada Socrates sebagai berikut: Socrates, apakah moral itu bisa diajarkan, atau hanya bisa dicapai melalui praktik kehidupan sehari-hari? Seandainya melalui pengajaran, pendidikan dan praktik tidak bisa dicapai, apakah nilai moral bisa dicapai secara alamiah atau dengan cara lain? Pertanyaan dan pernyataan Meno ini sampai sekarang masih terus menjadi perdebatan terutama di kalangan para ahli psikologi dan filsafat moral. Pertanyaan dan pernyataan tersebut, hingga pada masa sekarang ini dirumuskan sebagai berikut: apakah pendidikan moral diartikan dengan pendidikan tentang moral, atau apakah moral dimaksudkan agar manusia belajar menjadi manusia yang bermoral (Zuriah, 2007, h. 20-21).

Seiring dengan tujuan pendidikan nasional dan tujuan kelembagaan sekolah serta tujuan pendidikan moral yang diberikan pada tingkat sekolah hingga perguruan tinggi, maka pendidikan moral di Indonesia menurut Nurul Zuriah bisa dirumuskan untuk sementara, bahwa pendidikan moral adalah suatu program pendidikan (sekolah dan luar sekolah) yang mengorganisasikan dan menyederhanakan sumber-sumber moral dan disajikan dengan memperhatikan pertimbangan psikologis untuk tujuan pendidikan. Menurut paham ahli pendidikan moral, jika tujuan pendidikan moral akan mengarahkan seseorang menjadi bermoral, berakhlak mulia, yang terpenting adalah bagaimana agar seseorang dapat menyesuaikan diri dengan tujuan hidup bermasyarakat. Oleh karena itu, dalam tahap awal perlu dilakukan pengondisian moral (moral conditioning) dan latihan moral (moral training) untuk pembiasaan-pembiasaan (Zuriah, 2007, h. 22). Pendidikan moral adalah pengajaran tentang moral. Moral sebagaimana dimaksud adalah pengetahuan seseorang terhadap hal-hal yang baik atau buruk, atau merupakan kondisi pikiran, perasaan, ucapan dan perilaku manusia yang terkait dengan nilai-nilai baik dan buruk dan untuk mengetahui hal tersebut dan agar bersemi dan mengakar dalam hati dan pada diri seseorang, mengharuskan melalui proses pendidikan, latihan-latihan dan pembiasaan-pembiasaan. Sehingga bilamana sifat-sifat seseorang yang mengakar dalam hati yang mendorong munculnya perbuatan-perbuatan tanpa pertimbangan dan pemikiran, maka wujud perbuatan itulah menjadi karakter seseorang, yang oleh Imam al-Ghazali disebut sebagai akhlak. Istilah moral dan karakter adalah dua hal yang berbeda, moral seperti telah disebutkan adalah pengetahuan seseorang terhadap hal baik dan buruk, sedangkan karakter adalah tabi'at seseorang yang langsung di derive oleh 
otak. Dari sudut pandang pandang lain bias dikatakan bahwa tawaran istilah pendidikan karakter dating sebagai bentuk kritik dan kekecewaan terhadap praktek pendidikan moral selama ini. Karenanya, terminology yang ramai dibisarakan dan diperbincangkan sekarang ini adalah pendidikan karakter (character education) bukan pendidikan moral (moral education), walaupun secara substansial sesungguhnya keduanya tidak memiliki perbedaan yang prinsipil. Demikian pula halnya dengan istilah akhlak sebagaimana disebutkan, maka kaitannya dengan istilah pendidikan akhlak, merupakan upaya kea rah terwujudnya sikap batin yang mampu mendorong secara spontan lahirnya perbuatanperbuatan yang bernilai baik dari seseorang. Dalam pendidikan akhlak ini, menurut (Bardansyah, 2008, h. 5-6) bahwa kriteria benar dan salah untuk menilai perbuatan yang muncul merujuk kepada al-Quran dan al-Sunnah sebagai sumber tertinggi ajaran Islam. Dengan demikian, maka pendidikan akhlak bisa dikatakan sebagai pendidikan moral dalam diskursus pendidikan Islam". Pendapat lain akhlak disebut sebagai budi pekerti, yaitu kehendak yang biasa dilakukan atau segala sifat yang tertanam dalam hati yang menimbulkan kegiatan-kegiatan dengan ringan dan mudah tanpa memerlukan pemikiran sebagai pertimbangan (Rusyan, 2006, h. 3).

Memahami berbagai substansi makna tersebut di atas, maka dapat dikatakan bahwa sesungguhnya pendidikan moral ini merupakan suatu proses yang sengaja, di mana para warga muda (anak didik) dari masyarakat dibantu (dididik) supaya dapat berkembang dengan baik dari orientasi yang berpusat pada diri sendiri mengenai hakhak dan kewajiban mereka ke arah pandangan yang lebih luas, yaitu bahwa dirinya berada dalam masyarakat ke arah pandangan yang lebih mendalam mengenai dirinya (Salam, 2000, h. 76-77). Atau dengan kata lain, bahwa pendidikan moral adalah usahausaha yang dilakukan secara terencana untuk mengubah sikap, perilaku, tindakan, kelakuan yang dilakukan peserta didik agar mampu berinteraksi dan bersosialisasi dengan lingkungan masyarakatnya sesuai dengan nilai moral dan kebudayaan masyarakat setempat. Oleh karena itu, dalam proses pendidikan moral, para guru (pendidik) diharapkan untuk senantiasa membantu anak didik agar bisa berkembang lebih baik. Jadi yang diharapkan bukan hanya semata-mata supaya guru atau pendidik dapat menanamkan nilai-nilai moral secara indoktrinatif kepada para anak didik. Dalam proses pendidikan moral, harus dihindarkan pemaksaan nilai pada anak didik, sebaliknya diusahakan para anak didik, dididik, dibina atau dibimbing melalui suatu 
proses ke arah nilai-nilai sebagai rangsangan untuk berfikir atau berpaham secara positif. Dalam proses pendidikan moral selain metode contoh teladan harus dibarengi dengan metode yang bersifat rasional yakni anak diberi kesempatan untuk pro aktif dan kreatif, mengkritik dan mendiskusikan tentang moral yang harus dipatuhinya, sehingga ia mengerti mengapa ia harus mematuhi moral tersebut. Dalam hal tersebut, menurut (Nasution, 1996, h. 389), bahwa metode ideal yang dipergunakan dalam pendidikan moral oleh sang-pendidik, selain contoh teladan, juga metode tanya jawab dan diskusi dalam hal pendekatan intelektual tentang ajaran-ajaran moral”.

Pengertian moral dalam pendidikan moral di sini hampir sama saja dengan rasional di mana penalaran moral dipersiapkan sebagai prinsip berfikir kritis untuk sampai pada pilihan dan penilaian moral (moral choice and moral judgment) yang dianggap sebagai fikiran dan sikap terbaiknya (Zuriah, 2007, h. 22). Dengan demikian, dalam upaya pendidikan moral, daya kemampuan dan kekuatan rasio juga ikut berperan untuk mewujudkan nilai-nilai moral pada diri anak didik, sedangkan moral sendiri ditanamkan ke dalam jiwa anak didik sejalan dengan perkembangan daya kemampuan akal/rasio mereka. Hal tersebut, seiring apa yang dikatakan oleh (Miskawaih, 1977, h. 75) bahwa moral ditanamkan ke dalam diri anak didik ketika sudah mengenal rasa malu, karena rasa malu merupakan tanda sudah berkembangnya akal anak didik, oleh karena itu, pendidikan moral sangat terkait dengan akal atau rasio anak didik.

\section{Pendidikan Moral Perspektif Harun Nasution}

Untuk membentuk pribadi-pribadi yang bermoral, berkarakter berbudi pekerti luhur atau berakhlak mulia sebagaimana yang diharapkan oleh setiap orang, memang tidaklah semudah yang dibayangkan, hal ini sebagaimana telah disinggung haruslah melalui proses pendidikan yang berkesinambugan dan terpadu, baik dari keluarga, sekolah dan masyarakat. Selama ini terkesan pendidikan moral yang kita laksanakan belum seperti yang kita harapkan dan bahkan kita harus akui kurang berhasil, kemungkin itulah yang mengilhami sampai sekarang adanya istilah pendidikan karakter sebagai bentuk kritik sosial dan kekecewaan mendalam terhadap praktik pendidikan moral selama ini, sehingga masih banyak terjadi pelanggaran-pelanggaran sosial dan krisis moral di tengah-tengah kehidupan masyarakat. Betapa banyak sudah ilmuwanilmuwan di antara kita (ilmuwan agama sekalipun), justeru perilakunya tidak pernah 
mau sejajar dengan ilmu yang dimilikinya, bahkan merasa berbangga bila berbuat pelanggaran-pelanggaran sosial dan maksiat sekalipun. Sesuai apa yang dikatakan oleh Naquib Alatas, bahwa kecenderungan dikalangan para elit di Negara-negara berkembang, banyak tau hal yang buruk dan hal yang baik harus dilakukan, akan tetapi mereka senantiasa membiarkan yang buruk itu terus menerus dilakukan, bahkan mereka sendiri terlibat selalu melakukannya berulangkali. Orang yang tau bahwa yang dilakukannya salah dan buruk, tetapi tetap melakukannya, itu namanya orang bebal dalam istilah sosiologi (“Hari. Riau Pos,” 2007).

Kurang berhasilnya pendidikan moral selama ini, harus diakui barangkali disebabkan kurang tepatnya metode dan pendekatan yang kita pergunakan dalam proses pendidikan moral. Dalam pelaksanaan proses pendidikan moral selama ini kurang memperhatikan aspek-aspek rasionalitas anak didik misalnya, di mana ajaran moral ditanamkan kepada jiwa anak didik hanya secara doktrinatif semata dengan cara untuk dipaksa dan diharuskan mematuhi nilai-nilai moral tanpa diberi hak untuk mendiskusikan, menanyakan mengapa ia harus melakukannya, serta tidak diberi kesempatan kebebasan berpikir untuk mengkritik terhadap ketentuan moral yang kita haruskan kepada mereka, bahkan seolah-olah anak didik kita merupakan objek yang selalu siap menerima segala yang diperintahkan kepadanya. Pada hal, setiap anak didik memiliki potensi yang berupa daya akal/rasio, yang dengan rasionya anak didik mampu memikirkan, menganalisis dan memahami setiap perintah dan larangan yang ditujukan kepada mereka. Oleh sebab itu, pendidikan moral yang diberikan kepada seseorang harus senantiasa memperhatikan perkembangan dan daya kemampuan rasionalitasnya, sehingga pendidikan moral yang kita tanamkan dalam jiwa anak didik itu dapat diterima dengan mudah oleh akal sehatnya dan kemudian diamalkan di dalam kehidupannya sehari-hari. Pendidikan moral tidak dapat dilepaskan dari pendidikan agama, karena itu bahan ajarnya-pun sangat terkait dengan bahan ajar pendidikan agama. Menurut Harun Nasution, bahan pendidikan agama sebaiknya didasarkan pada tujuan moral, spiritual dan intelektual. Bahan ajar yang diberikan pada setiap jenjang pendidikan misalnya, harus tetap berkesinambungan dari nilai yang sederhana pada tingkat Taman Kanakkanak (TK) dan Sekolah Dasar (SD/sederajat) sampai yang bersifat filosofis pada tingkat Perguruan Tinggi (PT). Pemberian materi pada tingkat TK, SD, SMP dan SMA 
misalnya, ditekankan pada pendidikan moral dan agama, terutama pendidikan akhlak (budi pekerti) bukan pengajaran akhlak semata-mata (Nasution, 1996, h. 387).

Salah satu aspek yang dapat menguatkan pendidikan moral (akhlak) adalah meluaskan lingkungan alam fikiran (akal/rasio), di mana fikiran yang sempit merupakan sumber beberapa keburukan atau ketidak benaran, dan oleh karena itu akal (fikiran) yang kacau balau tidak mungkin akan dapat membuahkan akhlak yang tinggi dan mulia (Amin, 1977). Dengan demikian, akhlak/moral yang baik, mulia dan tinggi hanya akan lahir dari insan yang memiliki akal fikiran yang luas dan jernih (rasionalistis). Oleh karena itu, sebelum seseorang menerima pendidikan moral, maka akal fikirannya harus di arahkan, dibimbing dan dilatih, dididik dan dibiasakan untuk berfikir jernih dan tidak picik. Manusia yang memiliki rasio yang jernih dan bersih dari unsur-usur matrial akan sampai kepada tingkat akal mustafad yaitu akal atau rasio yang mampu mencari, menelusuri dan menemukan moral yang baik dan tinggi. Untuk mencapai tingkat akal yang sedemikian itu, tentu tidaklah mudah, tetapi harus melalui proses pendidikan dan latihan-latihan yang rutin terutama latihan rohani. Hal tersebut sesuai apa yang dikatakan oleh Muhmidayeli, bahwa untuk mengembangkan akal atau daya intelektual manusia, antara lain dengan cara memberikan kebebasan berpendapat, melatih berfikir konsekuensi, melatih berani dan bertanggungjawab, melatih kestabilan jiwa, serta melatih keteguhan hati dan semangat mencari kebenaran (Muhmidayeli, 2007, h. 126).

Dengan demikian, peran akal atau rasio manusia sangatlah besar dalam menentukan keberhasilan pendidikan moral, di mana rasio memberikan kontribusi yang tidak kecil dalam pendidikan moral itu sendiri. Moral yang tinggi dan baik akan diraih oleh manusia yang mampu mempergunakan rasio dalam menyeleksi segala perbuatannya, sedangkan rasio memiliki kemampuan untuk mengarahkan manusia kepada perilaku moral yang tinggi dan baik pula. Dalam ajaran Islam, dijelaskan bahwa jiwa manusia memiliki dua daya, yaitu daya berfikir yang disebut akal (rasio), berpusat di kepala, dan daya rasa yang disebut kalbu, berpusat di dada. Kedua daya tersebut, harus ditumbuh kembangkan serta dipertajam secara seimbang, sehingga dapat membimbing dan mengarahkan manusia ke jalan yang benar. Apabila terjadi ketidak seimbangan di antara keduanya daya berfikir dan daya rasa batin tersebut, maka akan menjadikan manusia yang tidak memiliki keseimbangan antara akal dan moralnya (Nasution, 1996, h. 391). Sangat boleh jadi sebagai orang yang berilmu, tetapi tidak 
berperilaku sejajar ilmu yang dimilikinya. Daya berfikir atau akal/rasio dapat dikembangkan dan dipertajam melalui penelitian, pemikiran dan perenungan terhadap ayat-ayat kauniyah (tanda-tanda ke alaman), di mana dengan hasil penelitian, pemikiran dan perenungan tersebut akan dapat mempertebal keyakinan dan ketakwaan kepada Allah SWT. Sedangkan daya rasa batin atau kalbu dapat dikembangkan dan dipertajam melalui ibadah, baik secara vertical maupun horizontal. Dengan demikian, apabila daya berfikir dan daya rasa batin sama-sama mendapat latihan dan pendidikan yang tepat, maka akan dapat menciptakan manusia yang memiliki akal/rasio yang handal serta kalbu yang santun. Dengan kata lain dapat menciptakan intelektual yang berakhlak mulia, dimana ilmu yang dimilikinya senantiasa di-backing oleh moral atau akhlaknya.

Metode atau cara-cara yang seharusnya dapat dipergunakan dalam proses pendidikan moral harus bervariasi, mulai dari proses pembiasaan-pembiasaan dan contoh teladan sampai pada proses tanya jawab dan diskusi. Melalui proses tanya jawab dan diskusi, akal/rasio anak didik akan dilatih untuk berfikir kritis dan analisis, dimana anak diberi kesempatan untuk menanyakan alasan mengenai suatu perbuatan harus dilaksanakan atau dijauhi. Dalam hal ini, anak didik tidak hanya disuruh mematuhi nilai-nilai moral, tetapi diberitahu alasannya ia harus mematuhi moral tersebut. Apabila anak mengerti tujuan dari perbuatannya, maka ia akan mau melaksanakan perbuatan tersebut meskipun tanpa diperintah. Dengan demikian, nilai-nilai moral yang kita tanamkan dalam jiwanya akan tetap terpatri, bersemi dan akan selalu dipatuhi walaupun di luar pengawasan pribadi dan control social. Oleh karena itu, jelaslah bahwa sesungguhnya proses pendidikan moral tidak dapat dilepaskan dari proses pendidikan akal/rasio. Akal merupakan kekuatan yang terdapat dalam jiwa manusia, dimana melalui akalnya manusia mampu memikirkan segala fenomena alam, sehingga mampu menciptakan ilmu pengetahuan dan teknologi (IPTEK), namun kemampuannya menciptakan ilmu pengetahuan dan teknologi tidak membuat dirinya angkuh dan sombong, tetapi malah menjadikan jiwanya (moral; imannya) semakin tunduk, taat dan patuh kepada yang memberi kemampuan tersebut. Menjadi manusia yang mempunyai misi ilmuwan menjadi ganda, pada satu sisi ia menjadi komunitas pencerah masyarakat, dan pada saat yang sama ia menjadi penshaleh bagi masyarakat. Apabila keadaan ini tidak berjalan seimbang, maka ketinggian nilai ilmu pengetahuan menjadi hilang maknanya. Ilmu yang dapat mencerahkan tetapi tidak dapat menshalehkan akan 
melahirkan manusia cerdas tetapi jahat. Sebaliknya, manusia yang hanya bermoral tetapi tidak berilmu seringkali akan menjadi objek dan komoditas yang selalu diperalat dan diombang-ambingkan pihak lain. Oleh kerana itu, yang kita dambakan lagi kita butuhkan saat ini adalah orang-orang baik, yang bermoral, berakhlak mulia, bukan orang dengan modal kepinteran semata-mata (Harahap, 2005). Dengan kata lain, bahwa yang sangat kita butuhkan sampai hari ini adalah manusia-manusia yang memiliki pengetahuan luas (intelektual muslim) sekaligus berakhlak mulia, sehingga mampu mengemban amanah atau tugas mulia sebagai khalifah di bumi ini untuk membagaimanakan sekaligus memakmurkan dunia, bukan justeru untuk membuat kerusakan, keonaran dan sebagainya sebagaimana halnya berbagai fenomena sosial yang kita saksikan hingga hari ini. Manusia yang memiliki keseimbangan antara kekuatan akal/rasio dengan moralnya, akan mampu melahirkan tindakan-tindakan yang bermoral pula. Sekiranya ia menjadi pemimpin misalnya, maka akan dapat dipastikan menjadi pemimpin yang shaleh-shalehah, santun, adil dan senantiasa akan mengutamakan kesejahteraan sosial umat. Seterusnya, bila ia menjadi sosok ilmuwan, akademisi maka ia akan dapat dipastikan memanfaatkan ilmunya demi untuk kemashalahatan orang banyak, bukan justeru untuk menyengsarakan orang banyak.

\section{Penutup}

Harun Nasution, merupakan salah seorang tokoh intelektual muslim pembaharu di bidang pemikiran Islam rasional di Nusantara Indonesia. Kajian dan studi-studi keislaman dengan khas ijtihadiyanya lebih mengandalkan sekaligus mengembangkan dominasi kemampuan daya nalar dan kekuatan rasio (akal) dalam memahami dan menjelaskan ajaran-ajaran agama dengan tetap memperhatikan substansi pesan-pesan moral wahyu ilahi, melalui al-Quran dan al-Hadits sebagai sumber utama syariat Islam. Menurut Harun Nasution dengan metode tersebut, maka ajaran-ajaran Islam dari berbagai aspeknya, akan menjadi fleksibel, dinamis, mudah dipahami dan diterima, bahkan mudah dalam proses pengamalannya.

Pemikiran-pemikiran Islam rasional seiring perkembangan zaman, tidak mungkin dapat dipisahkan dari proses pendidikan moral, karena dalam pandangan pemikiran Islam rasional, akal (rasio) manusia memiliki daya kemampuan akurat untuk menganalisis sekaligus memahami kebenaran-kebenaran dan nilai-nilai moral. 
Sementara dalam proses pendidikan moral itu sendiri semestinya disesuaikan dengan tingkat perkembangan kemampuan akal anak didik disamping harus rasional pula. Relevansi antara pendidikan moral dengan akal anak didik meliputi berbagai aspek, baik dari aspek materi bahan ajarnya, metode pendekatannya maupun sumber-sumber belajarnya. Keseimbangan antara pendidikan akal/rasio dengan pendidikan moral, pada gilirannya ada harapan akan melahirkan anak didik (generasi) yang tidak hanya memiliki akal yang cerdas dan pintar, melainkan juga akan memiliki perilaku budi pekerti luhur atau akhlak yang mulia, sebagai manusia pencerah sosial agamis. Keterkaitan antara materi-materi pendidikan yang mengembangkan rasio dengan materi pendidikan moral itu sendiri, dengan melalui penekanan dimensi moral, maka peserta didik dapat belajar nilai untuk membedakan mana yang salah, mana yang benar atau mana yang baik dan mana yang buruk.

\section{DAFTAR PUSTAKA}

Al-Qardhawi, Y. (1987). Ijtihad dalam Hukum Islam. (terjemahan Ahmad Syathari). Jakarta: Bulan Bintang.

Amin, A. (1977). Etika (terjemahan Farid Ma'ruf, edisi kedua). Jakarta: Bulan Bintang.

Bardansyah, Y. (2008). Pembentukan Karakte. Pekanbaru: LPP Fakutas Tarbiyah dan Keguruan UIN Suska Riau.

Depdiknas. (2006). Peraturan Menteri Pendidikan Nasional Republik Indonesia Nomor 22 Tahun 2006. Global Shadows: Africa in the Neoliberal World Order.

Halim, A. (2001). Teologi Islam Rasional (Pertama). Jakarta: Ciputat Press.

Harahap, S. (2005). Penegakan Moral Akademik di Dalam dan di Luar Kampus. Jakarta: PT. Grafindo Persada.

Harian Riau Pos. (2007). Harian Riau Pos, h. 2.

Hazm, I. (1978). Al-Ihkam Fi Ushul al-Ahkam. (terjemahan Muhammad Ahmad Abdul Aziz). Kairo: Maktabah 'Athif.

Khallaf, A. al W. (1956). 'Ilm Ushul al-Fiqh (Tujuh). Kairo: ar al Qalam.

Miskawaih, I. (1977). Tahzib al-Akhlak (terjemahan Helmi Hidayat) (Ketiga). Bandung: Mizan.

Muhmidayeli. (2007). Teori-teori Pengembangan Sumber Daya Manusia (Pertama). Pekanbaru: Program Pascasarjana UIN Suska dan LSFK2P.

Nasution, H. (1979). Akal dan Wahyu dalam Islam. Jakarta: UI Press.

Nasution, H. (1986). Teologi Islam Aliran-aliran Sejarah Analisa Perbandingan (kelima). Jakarta: UI Press. 
Nasution, H. (1996). Islam Rasional Gagasan dan Pemikiran (Empat). Jakarta: UI Press.

Nata, Abdul. (1995). Ilmu Kalam, Filsafat dan Tasawuf (edisi ketiga). Jakarta: PT. Raja Grafindo Persada.

Nata, Abuddin. (2000). Pemikiran Para Tokoh Pendidikan Islam. Seri kajian filsafat pendidikan Islam (Pertama). Jakarta: PT. Raja Grafindo Persada.

Putra, A. T. A. (2020). Konsep Pemikiran Ismail Raji Al Faruqi (Dari Tauhid Menuju Integrasi Ilmu Pengetahuan di Lembaga Pendidikan). Zawiyah: Jurnal Pemikiran Islam. https://doi.org/10.31332/zjpi.v6i1.1827

Rusyan, A. T. (2006). Pendidikan Budi Pekerti. Jakarta: PT Sinergi Pustaka Indonesia.

Salam, B. H. (2000). Etika Individual: Pola Dasar Filsafat Moral. PT Rineka Cipta (Pertama). Jakarta: Rineka Cipta.

Suminto, A. (1989). Refleksi Pebaharuan Pemikiran Islam (Pertama). Jakarta: Guna Aksara.

Tebba, S. (1989). Pembaharuan Hukum Islam mempertimbangkan Harun Nasution, dalam buku Aqib Suminto dkk. 1989. Refleksi Pembaruan Pemikiran Islam (Pertama). Jakarta: Guna Aksara.

Umar, H. . H. (2007). Nalar Fiqih Kontemporer (Pertama). Jakarta: Gaung Persada Press.

Yusuf, M. Y. (1989). Mengenal Harun Nasution melalui Tulisannya, dalam buku Aqib Suminto dkk. 1989. Refleksi pembaruan pemikiran Islam (Pertama). Jakarta: Guna Aksara.

Zuriah, N. (2007). Pendidikan Moral dan Budi Pekerti dalam Perspektif Perubahan Manggagas Platfom Pendidikan Budi Pekerti Secara Kontekstual dan Futuristik. Jakarta: Bumi Aksara. 